\title{
Faktor Keuangan Dan Kualitas Laba Perusahaan Manufaktur Di Indonesia
}

\author{
Asti April Lia ${ }^{1}$, Dirvi Surya Abas ${ }^{2}$, M Zulman Hakim ${ }^{3}$ \\ Universitas Muhammadiyah Tangerang ${ }^{1,2,3}$ \\ Koresponden Email : asti.aprillia18@gmail.com
}

\begin{abstract}
Abstrak: Tujuan penelitian ini adalah analisis: (1) Pengaruh likuiditas (CR) terhadap kualitas laba. (2) Pengaruh Return On Asset (ROA) terhadap kualitas laba. (3) Pengaruh Return On Equity (ROE) terhadap kualitas laba. (4) Pengaruh Leverage (DER) terhadap kualitas laba. (5) Pengaruh Total Asset Turn Over (TATO) terhadap kualitas laba. Populasi yang diteliti yaitu perusahaan manufaktur industry yang terdaftar di Bursa Efek Indonesia (BEI) Periode 2016-2018. Teknik pengambilan sampel menggunakan teknik sampling dan diperoleh sampel sebanyak 14 perusahaan dengan jumlah 42 pengamatan. Penelitian ini menggunakan metode observasi non partisipan yang diambil dari data laporan tahunan dan laporan keuangan perusahaan. Teknik analisis yang digunakan adalah analisis jalur (path analysis). Hasil penelitian ini yaitu: (1) Likuiditas tidak berpengaruh terhadap kualitas laba. (2) Return On Asset berpengaruh positif terhadap kualitas laba. (3) Return On Equity berpengaruh negative terhadap kualitas laba. (4) Leverage berpengaruh positif terhadap kualitas laba. (5) Total Assets Turn Over berpengaruh positif terhadap kualitas laba.
\end{abstract}

Kata Kunci: Likuiditas ; Return On Asset ; Return On Equity ; Leverage ; Total Assets Turn Over ; Kualitas Laba.

Laba yang digunakan untuk informasi yang ditunggu oleh pasar dan saat ini masih diyakini sebagai informasi utama sebagai kandungan informasi yang sangat penting karena dapat mempengaruhi investor-investor yang akan datang dalam membuat keputusan membeli, menjual, atau menahan sekuritas yang diterbitkan oleh perusahaan tersebut. Laba yang dihasilkan perusahaan, baik itu positif ataupun negative akan memberikan pengaruh pada respon pasar dan pergerakan harga saham (Syafrina, 2017 dalam Eksandy \& Milasari, 2019). Menurut (Sukmawati et al. 2014 dalam Eksandy dan Milasari, 2019), laba sebagai bagian dari laporan keuangan yang tidak menyajikan laporan keuangan yang sebenarnya dapat diragukan kualitasnya. Laba yang tidak menunjukkan informasi keuangan yang sebenarnya tentang kinerja manajemen dapat menyesatkan pihak pengguna laporan.

Salah satu contohnya dalam informasi laba yang diterbitkan oleh suatu perusahaan adalah kasus dari PT Telekomunikasi Indonesia Tbk (Telkom) mencetak pertumbuhan laba bersih sebesar $2 \%$ menjadi $R p \quad 7,4$ triliun pada paruh pertama tahun ini, dari $\mathrm{Rp} 7,29$ triliun laba bersih periode yang sama di tahun 2014. Kinerja tersebut dinilai di bawah ekspektasi pelaku pasar sehingga mengakibatkan menurunnya harga saham tersebut. Analis Mandiri Sekuritas Ariyanto Kurniawan menilai laba bersih Telkom tersebut tertekan biaya pemeliharaan yang lebih tinggi yang harus dibayarkan di paruh pertama tahun ini. "Selain itu biaya program pensiun dini Telkom juga tercatat lebih tinggi," jelas Ariyanto dalam riset, 
Senin (3/8). Seperti diketahui dalam enam bulan pertama tahun ini, Telkom mampu mencetak pertumbuhan pendapatan sebesar $12,17 \%$ secara tahunan, menjadi Rp 48,84 triliun. Dari lima bisnis yang dimiliki Telkom, peningkatan terbesar dalam semester I tahun ini disumbangkan oleh bisnis pendapatan jasa telekomunikasi lain. Secara rinci pendapatan lini bisnis itu melonjak $61,34 \%$ secara tahunan, diikuti jumlah pendapatan data internet, dan jasa teknologi informasi yang bertumbuh 20,48\% dari tahun sebelumnya. Sementara, pendapatan dari bisnis jaringan melemah menjadi $18,4 \%$ secara tahunan, pendapatan interkoneksi turun 6,05\%, serta pendapatan telepon menurun $4,85 \%$ dari tahun sebelumnya. Laba usaha semester I 2015 naik 7,47\% dari paruh pertama tahun lalu menjadi Rp 15,12 triliun. Di sisi lain, terdapat peningkatan di sejumlah pos beban, salah satunya beban operasi dan pemeliharaan yang menanjak 22,56 persen. (www.cnnindonesia.com)

\section{METODE}

Dalam penelitian ini objek penelitian yang didapat dari Bursa Efek Indonesia (BEl) yang tersedia disitus http://www.idx.co.id. Populasi dalam penelitian ini yaitu perusahaan manufaktur aneka industri di BEI periode 2016-2018 sebanyak 46 perusahaan. Pemilihan perusahaan secara purposive sampling diantaranya publish Laporan Tahunan secara konsisten selama periode penelitian, perusahaan yang Audited, menggunakan Rupiah dalam pelaporannya. Sehingga sampel yang digunakan dalam penelitian menjadi sebanyak 14 perusahaan. Jenis penelitian ini menggunakan pendekatan metode penelitian secara kuantitatif. Metode analisis data yang digunakan terdiri dari: analisis deskritif, analisis statistik dan analisis regresi data panel (eviews).

Tabel 1. Definisi Operasional Variabel

No Variabel Dimensi

1 Quality of kualitas laba dapat Income (Y) diukur Rasio Quality of Income menunjukkan varians antara arus kas dengan laba bersih..

Indikator

Skala

Rasio

$$
\begin{aligned}
& \text { QoF } \\
& =\frac{\text { Arus Kas Operasi }}{\text { EBIT }}
\end{aligned}
$$

2 Likuiditas (X1)

Rasio likuiditas yang
umum digunakan
adalah current ratio.
Current ratio yang tinggi
biasanya dianggap
menunjukkan tidak
terjadi masalah dalam
likuiditas, sehingga

Rasio

$$
C R=\frac{\text { Aktiva Lancar }}{\text { Hutang Lancar }}
$$
terjadi masalah dalam 
semakin

tinggi

likuiditas.

3 Return On Return on Asset (ROA) Asset (X2) menunjukkan efektifitas

perusahaan dalam mengelola aset baik dari modal sendiri maupun dari modal

$R O A$

$=\frac{\text { Laba Bersih Sesudah F }}{\text { Total Asset }}$ pinjaman, investor akan melihat seberapa efektif suatu perusahaan dalam mengelola aset.

Return On ROE digunakan untuk Equity (X3) mengukur kinerja

4 perusahaan dalam mengelola modal yang tersedia untuk menghasilkan laba.
$5 \quad$ Leverage (X4)

6
Pengukuran tingkat utang dengan membandingkan total utang dan total ekuitas

Total Assets TATO adalah rasio Turn Over (X5) penjualan terhadap total aktiva. TATO digunakan untuk mengukur seberapa efektifkah perusahaan dalam

$R O E$ $=\frac{\text { Laba Bersih Sesudah } \mathrm{F}}{\text { Total Ekuitas }}$

Rasio menggunakan seluruh aktiva perusahaan

\section{HASIL}

Tabel 2. Analisis Statistik Deskriptif

\begin{tabular}{|c|c|c|c|c|c|c|}
\hline & QOI & $\mathrm{CR}$ & ROA & ROE & DER & TATO \\
\hline Mean & 1.646552 & 2.152086 & 0.073850 & 0.127393 & 0.882431 & 1.196605 \\
\hline Median & 0.789400 & 1.730600 & 0.064950 & 0.115150 & 0.677250 & 0.930150 \\
\hline Maximum & 15.74980 & 7.680700 & 0.227300 & 0.317800 & 2.522300 & 4.158200 \\
\hline Minimum & -0.369800 & 0.648600 & 0.001200 & 0.002100 & 0.131300 & 0.649000 \\
\hline Std. Dev. & 2.883470 & 1.383244 & 0.057850 & 0.089691 & 0.703207 & 0.854781 \\
\hline Skewness & 3.369107 & 2.030417 & 1.251152 & 0.601501 & 1.232802 & 2.882369 \\
\hline Kurtosis & 15.44468 & 7.807434 & 4.219459 & 2.318033 & 3.272972 & 10.22834 \\
\hline Jarque-Bera & 350.4785 & 69.30314 & 13.56005 & 3.346514 & 10.76901 & 149.5921 \\
\hline Probability & 0.000000 & 0.000000 & 0.001136 & 0.187635 & 0.004587 & 0.000000 \\
\hline Sum & 69.15520 & 90.38760 & 3.101700 & 5.350500 & 37.06210 & 50.25740 \\
\hline Sum Sq. Dev. & 340.8905 & 78.44787 & 0.137210 & 0.329821 & 20.27453 & 29.95667 \\
\hline Observations & 42 & 42 & 42 & 42 & 42 & 42 \\
\hline
\end{tabular}

Nilai mean terbesar dialami oleh variabel Likuiditas (CR) yaitu sebesar 
2,152086, sementara variabel Return On Asset (ROA) memiliki nilai mean terkecil yaitu sebesar 0,073850.

Median adalah nilai tengah (rata-rata dua nilai tengah bila datanya genap) bila datanya diurutkan dari yang terkecil hingga yang terbesar (Winarno, 2015: 3.9). Median terbesar dialami oleh variabel Likuiditas (CR) yaitu sebesar 1,730600, sementara variabel Return On Asset (ROA) memiliki median terkecil yaitu sebesar 0.064950 .

Maximum adalah nilai paling besar dari data (Winarno, 2015: 3.9). Maximum terbesar dialami oleh variabel Kualitas Laba (QOI) yaitu sebesar 15,74980, sementara variabel Return On Asset (ROA) memiliki maximum terkecil yaitu sebesar 0,227300.

Minimum adalah nilai paling kecil dari data (Winarno, 2015: 3.9). Minimum terbesar dialami oleh variabel Total Asset Turn Over (TATO) yaitu sebesar 0,649000 sementara variabel Kualitas Laba memiliki nilai minimum terkecil yaitu sebesar -0.369800 .

Std. Dev (standard deviation) adalah ukuran dispresi atau penyebaran data (Winarno, 2015: 3.10). Nilai standar deviasi terbesar dialami oleh Kualitas Laba (QOI) yaitu 2.883470 yang berarti bahwa variable Kualitas Laba (QOI) memiliki tingkat risiko yang lebih tinggi dibandingkan dengan variabel-variabel lainnya. Sementara varibael Profitabilitas (ROA) mempunyai tingkat risiko yang paling rendah, yaitu sebesar 0,057850. Hal ini menunjukkan bahwa variabel ROA selama periode penelitian mengalami perubahan yang tidak terlalu fluktuatif.

Skewness adalah ukuran asimetri distribusi data disekitar mean. Skewness dari suatu distribusi simetris (distribusi normal) adalah 0 (nol). Positive skewness menunjukkan bahwa distribusi datanya memiliki ekor panjang disisi kanan dan negative skewness memiliki ekor panjang disisi kiri (Winarno, 2015: 3.10). Untuk variabel QOI, CR, ROA, DER, dan TATO memiliki nilai diatas 0 (nol) yang berarti bahwa asimetri distribusi data disekitar mean tidak normal, sedangkan variabel Return On Equity (ROE) memiliki nilai disekitar 0 (nol) yang berarti bahwa asimtri distribusi data disekitar mean bersifat normal.

Kurtosis mengukur ketinggian suatu distribusi. Kurtosis suatu data berdistribusi normal adalah 3. Bila kurtosis melebihi 3, maka distribusi data dikatakan leptokurtis terhadap normal. Bila kurtosis kurang dari 3, distribusi datanya datar (platykurtic) dibandingkan dengan data berdistribusi normal (Winarno, 2015: 3.10). Untuk variabel QOI, CR, ROA, DER dan TATO.memiliki nilai kurtosis lebih dari 3 yang berarti bahwa ketinggian distribusi data tidak normal, sementara variabel ROE memiliki nilai kurtosisi kurang dari 3 yang berarti bahwa ketinggian distribusi data bersifat normal.

Jarque-Bera adalah uji statistic untuk mengetahui apakah data berdistribusi normal. Uji ini mengukur perbedaan skewness dan kurtosis data dan dibandingkan dengan apabila datanya bersifat normal. Dengan Ho pada data berdistribusi normal, uji Jarque-Bera didistribusi dengan X2 dengan derajat bebas (degree of freedom) sebesar 2 . 
Probability menunjukkan kemungkinan nilai Jarque-Bera melebihi (dalam nilai absolut) nilai terobservasi di bawah hipotesis nol. Nilai probabilitas yang kecil cenderung mengarahkan pada penolakan hipotesis nol distribusi normal. Nilai probabilitas variabel Return On Equity (ROE) sebesar 0,187635 (lebih besar dari $\alpha=5 \%$ ), kita tidak dapat menolak $\mathrm{HO}$ bahwa data berdistribusi normal. Normal atau tidaknya distribusi data dalam analisis statistic deskriptif tidak membuat suatu penelitian gagal untuk dilakukan. Analisis statistic deskriptif digunakan hanya untuk melihat gambaran distribusi data yang akan diteliti saja.

Tabel 3. Rangkuman Hasil Pengujian Metode Penelitian

Effects Test

Cross-section $\mathrm{F}$

Cross-section Chi-

square

Test Summary

Cross-section

random

Breusch-Pagan

F-statistic
Prob(F-statistic)

R-squared

Statistic 0.608565

12.416413

d.f.

$(13,23)$

13

0.8226

0.4938

\section{Uji Hausman}

Chi-Sq. Chi-Sq. d.f.

Statistic

5.950314

5

0.3111

Uji Lagrange Multiplier

Test Hypothesis

Cross-

Time

Both

section

$\begin{array}{cll}4.035076 & 0.236706 & 4.271782 \\ (0.0446) & (0.6266) & (0.0388)\end{array}$

Uji Kelayakan Model (Uji F)

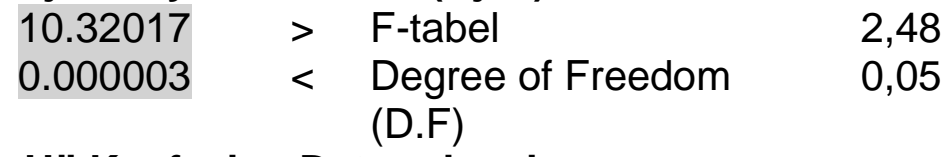

\section{Uji Koefesien Determinasi}

0.589045

0.531968

Adjusted R-squared

Sumber : Data diolah Eviews 9.0

Berdasarkan hasil Output Eviews 9 dalam Tabel 3 terlihat bahwa Uji Chow menunjukkan nilai Probabilitas Cross-section F dan Crosssection chi-quare $>\alpha(0,05)$, maka dapat disimpulkan bahwa Common Efect Model (CEM) lebih layak digunakan dibandingkan Fixed Effect Model (FEM). Selanjutnya Hasil Uji Hausman menunjukkan nilai Probabilitas (Prob.) Cross-section random $>\alpha(0,05)$, maka dapat disimpulkan bahwa Random Effect Model (REM) lebih layak digunakan dibandingkan Fixed Effect Model (FEM). Dan terakhir hasil Uji Lagrange Multipiler menunjukkan nilai Probabilitas Cross-section Breausch-pagan > 
a $(0,05)$, maka dapat disimpulkan bahwa Random Effect Model (REM) lebih layak digunakan dibandingkan Common Effect Model (CEM).

Berdasarkan hasil ke tiga pengujian yang sudah dilakukan maka dapat disimpulkan bahwa Model Regresi Data Panel yang akan digunakan dalam Uji Hipotesis dan persamaan Regresi Data Panel adalah model Berdasarkan hasil Output Eviews 9 Uji F diatas menunujukkan bahwa nilai F-statistic sebesar 10,32017, sementara $F$ tabel dengan tingkat 5\%, df1(k1) $=5$ dan df2 $(n-k)=36$ didapat nilai $F$ Tabel sebesar 2,48. Dengan demikian F-statistic $(10,32017)>\mathrm{F}$ tabel $(2,48)$ dan nilai Prob (F-statistic) $0,000003<0,05$ maka dapat disimpulkan bahwa Ha diterima, maka dengan demikian dapat disimpulkan bahwa variabel - variabel independen dalam penelitian ini yang terdiri dari CR, ROA, ROE, DER dan TATO secara bersama-sama memiliki pengaruh terhadap Kualitas Laba.

Koefisien Determinasi menunjukkan bahwa nilai Adjusted R-squared sebesar 0,589045, artinya bahwa variabel perubahan naik turunnya Kualitas Laba dapat dijelaskan oleh CR, ROA, ROE, DER dan TATO sebesar 58,9 persen, sementara sisanya yaitu sebesar 42,1 persen dijelaskan oleh variabel-variabel lain yang tidak diteliti dalam penelitian ini.

$$
\begin{aligned}
& \mathrm{Y}=-2.351684+0.069616 \mathrm{CR}+47.78942 \mathrm{ROA}- \\
& 34.95292 \mathrm{ROE}+2.550285 \mathrm{DER}+2.107187 \\
& \mathrm{TATO}+\mathrm{e}
\end{aligned}
$$

Tabel 5. Hasil Rangkuman Hipotesis Penelitian
N
Hipotesis
Signifikansi
Hasil
O
1. $\mathrm{H}_{1}$ : Likuiditas tidak berpengaruh terhadap kualitas laba
t-statistic
Ditolak
0.205727
Prob. 0.8382
t-statistic
Diterim
2. $\mathrm{H}_{2}$ : Return on Asset (ROA) berpengaruh positif Terhadap Kualitas Laba
2.118276
a
Prob. 0.0411
t-statistic -
Diterim
2.564244
negative Terhadap Kualitas Laba
Prob. 0.0147
4. $\mathrm{H}_{4}$ : Leverage berpengaruh positive Terhadap Kualitas Laba
t-statistic
a
3.202702
Diterim
Prob. 0.0028
t-statistic
a
5. $\mathrm{H}_{5}$ : Total Assets TurnOver berpengaruh
4.565536
Diterim
positive Terhadap Kualitas Laba
Prob. 0.0001
a

Sumber : Data diolah Eviews 9.0 
Likuiditas perusahaan menunjukkan koefisien positif sebesar 0,069616 dengan tingkat signifikansi sebesar $0,8382>\alpha=0,05$. Karena tingkat signifikan lebih besar dari $\alpha=0,05$ maka $\mathrm{H} 1$ ditolak sehingga simpulannya adalah likuiditas perusahaan tidak berpengaruh terhadap kualitas laba, namun likuiditas memiliki arah yang positif terhadap kualitas laba.Hasil penelitian sejalan dengan penelitian yang dilakukan oleh Soly dan Wijaya, (2017) yang menyatakan bahwa likuiditas perusahaan tidak berpengaruh terhadap kualitas laba. Namun penelitian ini tidak sejalan dengan penelitian yang dilakukan oleh (Silfi, 2016) yang menyatakan bahwa likuiditas perusahaan berpengaruh positif terhadap kualitas laba.

Return On Asset perusahaan menunjukkan koefisien positif sebesar 47,78942 dengan tingkat signifikansi sebesar 0,0411< $\alpha=0,05$. Karena tingkat signifikan lebih kecil dari $\alpha=0,05$ maka $\mathrm{H} 2$ diterima sehingga simpulannya adalah Return On Asset (ROA) memiliki pengaruh terhadap kualitas laba. Penelitian ini berhasil membuktikan adanya pengaruh Return On Asset terhadap kualitas laba, koefisien regresi bernilai positif. Hasil penelitian ini sejalan dengan penelitian yang dilakukan oleh Soly dan Wijaya (2017) yang menunjukkan bahwa Return On Asset berpengaruh positif terhadap kualitas laba, namun penelitian ini tidak sejalan dengan penelitian yang dilakukan oleh (Setiawan, 2017) yang menyatakan bahwa return on asset tidak berpengaruh terhadap kualitas laba.

Return On Equity perusahaan menunjukkan koefisien negative sebesar -34,95292 dengan tingkat signifikansi sebesar 0,0147 < $\alpha=0,05$. Karena tingkat signifikan lebih kecil dari $\alpha=0,05$ maka $\mathrm{H} 3$ diterima sehingga simpulannya adalah Return On Equity (ROE) memiliki pengaruh terhadap kualitas laba. Penelitian ini berhasil membuktikan adanya pengaruh Return On Equity terhadap kualitas laba, koefisien regresi bernilai negative. Hasil penelitian ini sejalan dengan penelitian yang dilakukan oleh (Machdar, 2017) yang menunjukkan bahwa Return On Equity berpengaruh negatif terhadap kualitas laba, namun penelitian ini tidak sejalan dengan penelitian yang dilakukan oleh Oktayanti dan Murtanto (2016) yang menunjukkan bahwa Return On Equity tidak berpengaruh terhadap kualitas laba.

Leverage perusahaan menunjukkan koefisien positif sebesar 2,550285 dengan tingkat signifikansi sebesar $0,0028<\alpha=0,05$. Karena tingkat signifikan lebih kecil dari $\alpha=0,05$ maka $\mathrm{H} 4$ diterima sehingga kesimpulannya adalah Leverage memiliki pengaruh terhadap kualitas laba. Penelitian ini berhasil membuktikan adanya pengaruh leverage terhadap kualitas laba, koefisien regresi bernilai positif. Hasil penelitian ini tidak sejalan dengan penelitian yang dilakukan oleh Laoli dan Herawaty (2019) menyatakan bahwa Leverage berpengaruh negatif terhadap kualitas laba.

Total Asset Turn Over perusahaan menunjukkan koefisien positif sebesar 2,107187 dengan tingkat signifikansi sebesar 0,0001 $<\alpha=0,05$. Karena tingkat signifikan lebih kecil dari $\alpha=0,05$ maka H5 diterima 
sehingga simpulannya adalah Total Asset Turn Over (TATO) memiliki pengaruh terhadap kualitas laba. Penelitian ini berhasil membuktikan adanya pengaruh Total Asset Turn Over terhadap kualitas laba. Koefisien regresi bernilai positif. Hasil penelitian ini sejalan dengan penelitian yang dilakukan oleh (Nurdiwaty, 2014) menyatakan bahwa total asset turn over (TATO) berpengaruh positif terhadap kualitas laba, namun penelitian ini tidak sejalan dengan penelitian yang dilakukan oleh (Nathania, 2017) yang menyatakan bahwa total asset turn over (TATO) tidak berpengaruh terhadap kualitas laba.

\section{KESIMPULAN}

Penelitian ini memiliki tujuan untuk mengetahui pengaruh likuiditas, Retun On Asset, Return On Equity, Leverage dan Total Assets Turn Over terhadap kualitas laba dengan menggunakan perusahaan aneka industry yang terdaftar di Bursa Efek Indonesia yang terdaftar dari tahun 20162018 sebagai objek penelitian dengan total sampel sebanyak 14 perusahaan dari total 42 populasi perusahan, dan analisis menggunakan regresi data panel.

Keterbatasan

Beberapa keterbatasan dalam penelitian ini adalah sebagai berikut:

Penelitian ini hanya menggunakan perusahaan manufaktur sektor industry sebagai objek penelitian dan tidak mengikutsertakan sektor lain. Periode pengamatan dalam penelitian ini sangat singkat memiliki rentang waktu 3 tahun dari tahun 2016-2018.

Penelitian ini di masa mendatang diharap agar dapat menyajikan hasil penelitian yang lebih berkualitas lagi dengan adanya beberapa masukan diantaranya sebagai berikut:

Penelitian ini diharapkan agar memberikan pengetahuan serta wawasan yang lebih luas tentang kualitas laba, hasil penelitian dan ilmu yang berkaitan dengan materi selama masa perkuliahan yang terdapat dalam penelitian ini.

Diharapkan agar dapat memberikan manfaat bahwa pentingnya memberikan informasi yang berkualitas terhadap investor. Dan seberapa besar pengaruh likuiditas, return on asset, return on equity, leverage dan total assets turn over terhadap kualitas laba.

Diharapkan dapat menjadi suatu sarana pertimbangan bagi calon investor untuk memilih investasi diperusahaan yang tepat, sehingga bisa memperoleh laba dan menghindari resiko.

\section{DAFTAR PUSTAKA}

Ananda, R., \& Ningsih, E. S. (2016). Pengaruh Likuiditas, Kepemilikan Institusional, Dan Ukuran Perusahaan Terhadap Kualitas Laba (Pada Perusahaanmanufaktur Yang Terdaftar Di Bursa Efek Indonesia Tahun 2010-2014). Jurnal Ilmiah Mahasiswa Ekonomi Akuntansi (JIMEKA), 1(2), 277-294. 
Arifin, M. (2016). Pengaruh Kinerja Keuangan Perusahaan Bidang Kelautan Yang Terdaftar di Bursa Efek Indonesia Terhadap Kualitas Laba.

Beautric, D., Sasongko, H., \& Simamora, P. (2019). Pengaruh Current Ratio, Debt To Equity Ratio, Tingkat Suku Bunga dan Nilai Tukar terhadap Return Saham Pada Perusahaan Sub Sektor Perkebunan yang Terdaftar Di Bursa Efek Indonesia Tahun 2014-2017. Manajemen, 1-17.

Darmawan, \& Lifatin, N. (2019). Fund Age, BI Rate, Exchange Rate, Dan Jakarta Islamic Index Pada Net Asset Value Di Islamic Equity Mutual Fund Indonesia. Jurnal Manajemen, 10(1). https://doi.org/10.32832/jm-uika.v10i1.1750

Dewi, C. (2018). Pengaruh Ukuran Perusahaan, Struktur Modal, Likuiditas, Invesment Opportunity Set dan Pertumbuhan Laba Terhadap Kualitas Laba Perusahaan.

Eksandy, A., \& Hakim, M. Z. (2018). Faktor-Faktor Yang Berpengaruh Terhadap Pengungkapan Islamic Social Reportingpada Perbankan Syari'ah Indonesia Periode 2011- 2015. Jurnal Akuntansi Maranatha, 10(2), 187-198. https://doi.org/10.28932/jam.v10i2.1084

Eksandy, A., \& Milasari, E. (2019). Pengaruh Environmental Disclosure, Kualitas Auditor Internal, dan Kontrak Manajemen Terhadap Kualitas Laba (Pada Perusahaan Indeks Kompas 100 yang Terdaftar di Bursa Efek Indonesia Periode 2013-2016). 88-113.

Ginting, S. (2017). Pengaruh Profitabilitas, Likuiditas dan Ukuran Perusahaan Terhadap Kualitas Laba Pada Perusahaan Manufaktur Yang Terdaftar di Bursa Efek Indonesia. Jurnal Wira Ekonomi Mikroskil, 7(2), 227-236.

Laoli, A. N., \& Herawaty, V. (2019). Pengaruh Profitabilitas, Growth, Leverage, Operating Cycle dan PPrudence TerhadaP Kualitas Laba Dengan Firm Size Sebagai Variabel Moderasi. 1-7.

Listyawan, B. (2017). Pengaruh Struktur Modal, Likuiditas, Ukuran Perusahaan, Pertumbuhan Laba dan Profitabilitas Terhadap Kualitas Laba.

Machdar, N. M. (2017). Pengaruh Karakteristik Perusahaan Terhadap Pengungkapan Pelaporan Serta Implikasinya Terhadap Kualitas Laba. 61-88.

Nasution, L. M. (2017). Statistik Deskriptif. Jurnal Hikmah, 14(1), 49-55.

Nathania, D. P. (2017). Analisis perbedaan kinerja perusahaan sebelum dan sesudah penerapan Employee Stock Option Program Serta Dampak Manajemen Laba Sebagai Variabel Moderasi. Jurnal Akuntansi Bisnis, 15(1), 101-127.

Nurdiwaty, D. (2014). Analisis Pengaruh Quick Ratio, Debt To Equity Ratio, Total Assets Turnover Net Profit Margin dan Price Earning Ratio Terhadap Laba. 12(1), 25-38.

Oktayanti, N. K. A., \& Murtanto. (2016). Analisis Pengaruh Tingkat Kesehatan Bank Terhadap Kualitas Laba Dengan Pendekatan 
Resiko Pada Bank Bumn Di Indonesia. Jurnal Akuntansi Trisakti, 3(1), 1-22. https://doi.org/10.25105/jat.v3i1.4912

Palimbong, M. (2015). Analisis Tingkat Kesehatan Bank Terhadap Kualitas Laba Pada Bank Umum Swasta Nasional Devisa Seindonesia (2008-2013). Skripsi.

Pitria, E. (2017). Pengaruh Kesempatan Bertumbuh, Leverage dan Profitabilitas Terhadap Kualitas Laba. Artikel . Fakultas Ekonomi Universitas Negeri Padang.

Prastiani, S. C. (2018). Pengaruh Kinerja Keuangan Terhadap Peringkat Obligasi Dengan Manajemen Laba Sebagai Variabel Intervening Pada Perusahaan Manufaktur yang Terdaftar di BEI. Jurnal Akuntansi Berkelanjutan Indonesia, 1(1), 1-23.

Setiawan, B. R. (2017). Pengaruh Ukuran Perusahaan,Profitabilitas, Likuiditas dan Leverage terhadap Kualitas Laba Pada Perusahaan Manufaktur Industri Barang Konsumsi Yang Terdaftar di BEI. MENARA IImu, XI(77), 243-255.

Silfi, A. (2016). Pengaruh pertumbuhan laba, struktur modal, likuiditas dan komite audit terhadap kualitas laba. Jurnal Valuta, 2(1), 17-26.

Soly, N., \& Wijaya, N. (2017). Faktor-Faktor Yang Mempengaruhi Kualitas Audit. JURNAL BISNIS DAN AKUNTANSI, 19(1), 47-55. https://doi.org/10.32492/eba.v5i1.712

Warianto, P., \& Rusiti, C. (2014). Pengaruh Ukuran Perusahaan, Struktur Modal, Likuiditas dan Investment Opportunity Set (IOS) Terhadap Kualitas Laba Pada Perusahaan Manufaktur yang Terdaftar di BEl. 26(1), 19-32.

Zulman, M., \& Abbas, D. S. (2019). Pengaruh Ukuran Perusahaan, Struktur Modal, Likuiditas, Investment opportunity Set (IOS) dan Profitabilitas terhadap Kualitas Laba. 26-51. 